\title{
Potentiometric determination of cysteine with thiol sensitive silver-mercury electrode ${ }^{\star}$
}

\author{
Ryszard Drożdż, Jerzy Naskalski® and Anna Ząbek-Adamska \\ Department of Diagnostics, Chair of Clinical Biochemistry, Collegium Medicum, Jagiellonian University, \\ Kraków, Poland
}

Received: 06 November, 2006; revised: 02 February, 2006; accepted: 16 February, 2007

available on-line: 09 March, 2007

\begin{abstract}
A potentiometric procedure for cysteine thiol group concentration monitoring in media generating free radicals was developed using a thiol specific silver-mercury electrode. Electrolytic deposition of mercury on a silver wire and treatment with $20 \mathrm{mM}$ cysteine in $0.5 \mathrm{M} \mathrm{NaOH}$ were used to produce the electrode. A silver-chloride electrode in saturated $\mathrm{KCl}$ was the reference. A glass capillary with $1 \mathrm{M} \mathrm{KNO}_{3}$ in $1 \%$ agarose gel was the liquid junction. The electrode responded to cysteine concentration in the range from 0.01 to $20 \mathrm{mM}$ yielding a perfect linear relationship for the dependence of $\log$ [cysteine] versus electrode potential $[\mathrm{mV}]$, with $\mathbf{b}_{0}$ (constant) $=-373.43$ $[\mathrm{mV}], \mathrm{b}_{1}$ (slope) $=-53.82$ and correlation coefficient $\mathrm{r}^{2}=0.97$. The electrode potential change per decade of cysteine concentration was $57 \mathrm{mV}$. The minimal measurable signal response was at a cysteine concentration of $0.01 \mathrm{mM}$. The signal CV amounted to $4-6 \%$ for cysteine concentrations of 0.01 to $0.05 \mathrm{mM}$ and to less than $1 \%$ for cysteine concentrations of 0.5 to $20 \mathrm{mM}$. The response time ranged from about $100 \mathrm{~s}$ for cysteine concentrations of 0.01 to $0.1 \mathrm{mM}$ to $30 \mathrm{~s}$ at higher cysteine concentrations. The standard curve reproducibility was the best at cysteine concentrations from 0.1 to $20 \mathrm{mM}$. In a reaction medium containing cysteine and copper(II)-histidine complex $\left([\mathrm{His}-\mathrm{Cu}]^{2+}\right.$ ) solution in $55 \mathrm{mM}$ phosphate buffer $\mathrm{pH}$ 7.4 the electrode adequately responded to changes in cysteine concentration. Beside cysteine, the silver-mercury electrode responded also to thiol groups of homocysteine and glutathione, however, the Nernst equation slope was about half of that for cysteine.
\end{abstract}

Keywords: cysteine, glutathione, homocysteine, potentiometry, real time assay

\section{INTRODUCTION}

The thiol residues of cysteine, glutathione and other low molecular mass peptides are readily oxidized in electrochemical reactions on the surface of various thiol sensitive electrodes. These reactions have been employed in a number of methods for electrochemical determination of thiol compounds. In the vast literature concerning electrochemical determination of thiol compounds, various types of electrodes including: mercury (Heyrovsky et al., 1997; Lawrence et al., 2001), silver (Yosipchuk \& Novotny, 2002; Kolar et al., 2002), gold (Yang et al., 2001; Ozoemena et al., 2001; Kolar et al., 2002), platinum (Zhao et al., 2001), tungsten (Hidayat et al., 1997), copper (Yang et al., 2001; Yosipchuk \& Novotny, 2002) and cobalt (Sugawara et al., 1996) have been described. These electrodes, predominantly used in potentiometric measurement, have been designed for various purposes, such as determination of thiol compounds in pharmaceutical products (Kolar et al., 2000; 2002; Kolar \& Dobcnik, 2003) or specific biological samples (Jin \& Wang, 1997; Calvo-Marzal et al., 2006). In some studies free radical formation in the presence of cysteine in the reaction medium was described (Kachur et al., 1999). We attempted to study cysteine involvement in the process, but most of the cysteine assay methods used to date, including HPLC, con-

\footnotetext{
${ }^{\star}$ Results of the experiments described in this paper were in part presented on the 41st Meeting of the Polish Biochemical Society, Białystok, Poland; September 12-15, 2006.

${ }^{\square}$ Corresponding author: Jerzy W. Naskalski, Zakład Diagnostyki, Katedra Biochemii Klinicznej CM UJ, Kopernika 15B, 31-501 Kraków, Poland; tel./fax (48 12) 424 8361; e-mail mbnaskal@cyf-kr.edu.pl
} 
sidered as cysteine assay gold standard, were unsuitable for this purpose. In this paper a method of real time monitoring of cysteine concentration changes in the reaction medium, employing a cysteine-sensitive silver-mercury electrode is described.

\section{MATERIALS AND METHODS}

Working solutions and dilutions of the reagents were prepared using glass-distilled water (with resistivity of $18 \mathrm{M} \Omega / \mathrm{cm}$, Millipore-Q). Stock solution of DL-cysteine $(20 \mathrm{mM})$ was prepared in 55 $\mathrm{mM}$ sodium phosphate buffer $\mathrm{pH}$ 7.4. Dilutions of DL-cysteine solution with this buffer were prepared directly prior to use. The final $\mathrm{pH}$ of the employed DL-cysteine solutions was adjusted to 7.4 by adding $0.5 \mathrm{M} \mathrm{NaOH}$. Oxidation of cysteine was carried out in a solution of a histidine-copper complex [His$\mathrm{Cu}]^{2+}$ obtained by mixing equal volumes of $\mathrm{CuCl}_{2}$ and histidine.

All reagents were obtained from Sigma and were of analytical grade.

The electrochemical measurements were carried out using an Elmetron CP-401 millivoltmeter. Measurement results were recorded on-line on a computer and final data were calculated using SigmaPlot v.7.0 program. The electrochemical potential of the electrodes studied was measured versus a reference $\mathrm{Ag} / \mathrm{AgCl}$ electrode in saturated $\mathrm{KCl}$ solution.

Working electrodes tested. Selection of a working cysteine sensitive electrode was carried out basing on a comparison of the analytical performance of eight different electrodes potentially useful for real time monitoring of cysteine concentration in the studied samples. The assessment of the electrode's properties included: electrode sensitivity, signal response rate, concordance of response with the Nernst equation, variation of the electrode response and specificity versus other thiol compounds. Platinum, copper, graphite, graphite-silver, graphite-silver-cysteine, silver, silver-iodide and silver-mercury electrodes were characterized.

Preparation of working electrodes. To prepare cysteine sensitive graphite, platinum, copper, and silver electrodes the electrode base material (25 mm long graphite rod or metal wire $0.7 \mathrm{~mm}$ in diameter) was cleaned mechanically with a low mesh sand paper, connected to a voltmeter by an insulated copper lead and fixed in a glass tube housing, using epoxy resin. Then the electrode was placed in $20 \mathrm{mM}$ cysteine in $0.5 \mathrm{M} \mathrm{NaOH}$ solution for $24 \mathrm{~h}$.

The graphite-silver electrode was prepared by electrolytic deposition of silver on a graphite rod and further treatment as described above for metal wire electrodes. The graphite-silver-cysteine elec- trode was the graphite-silver electrode which, after deposition of silver on the electrode surface, was subjected to cathode reduction in $20 \mathrm{mM}$ cysteine solution in $1 \mathrm{M} \mathrm{NaOH}$ for 2 min employing $2 \mathrm{~V}$ potential. Then the electrode was washed with water and placed in $20 \mathrm{mM}$ cysteine in $0.5 \mathrm{M} \mathrm{NaOH}$ solution.

The silver-mercury electrode was prepared using a silver wire inserted in a glass tube handle. The electrode surface was activated first for 5-10 s treatment with $0.5 \mathrm{M} \mathrm{NH}_{3}$ water solution, the electrode then was washed with distilled water, placed for $2 \mathrm{~min}$ in $0.1 \mathrm{M} \mathrm{HgCl}_{2}$ solution and mercury was deposited by electrolysis on the electrode surface. Then, the wire was again washed with distilled water and placed in $20 \mathrm{mM}$ cysteine in $0.5 \mathrm{M} \mathrm{NaOH}$.

The silver-iodide electrode was prepared as described by Kolar and coworkers (2002). Mechanically cleaned silver wire was placed for $5 \mathrm{~min}$ in $0.1 \mathrm{M} \mathrm{HgCl}_{2}$ solution, then washed with water and placed for $24 \mathrm{~h}$ in $0.1 \mathrm{M} \mathrm{KI}$. The electrode was stored in $0.1 \mathrm{M}$ KI solution.

The prepared working electrodes were stable and suitable for use for at least 10 days if stored in $20 \mathrm{mM}$ cysteine in $0.5 \mathrm{M} \mathrm{NaOH}$. Prior to each series of measurements the electrodes were washed with 55 $\mathrm{mM}$ phosphate buffer, $\mathrm{pH}$ 7.4, and the electrode initial potential was measured versus reference silverchloride $(\mathrm{Ag} / \mathrm{AgCl})$ electrode in $1 \mathrm{M} \mathrm{KNO}_{3}$ solution. Measurements were carried out after stabilization of the electrode initial potential (from $20 \mathrm{~s}$ to $30 \mathrm{~min}$ for different electrodes tested). After measurements, the electrodes were washed with $55 \mathrm{mM}$ phosphate buffer, $\mathrm{pH} 7.4$, and stored again in $20 \mathrm{mM}$ cysteine in $0.5 \mathrm{M} \mathrm{NaOH}$.

Reference silver-chloride (Ag/AgCl) electrode. The reference electrode was a silver-chloride electrode in saturated $\mathrm{KCl}$. The reference electrode cell was a $2.5 \mathrm{ml}$ microvial with $1 \mathrm{M} \mathrm{KNO}_{3}$. Fresh, saturated $\mathrm{KCl}$ solution in the silver-chloride reference electrode and fresh $1 \mathrm{M} \mathrm{KNO}_{3}$ solution in the reference electrode chamber were used at each new measurement series.

Preparation of the liquid junction. A Ushaped glass capillary with $1 \mathrm{M} \mathrm{KNO}_{3}$ in $1 \%$ agarose gel was used as the liquid junction. The measurement of the electrode potential was initiated by connecting the measuring cell with the reference electrode cell by placing the liquid junction into the workcell and the reference electrode cell. Each measurement series was carried out employing a new liquid junction capillary with a fresh agarose $/ \mathrm{KNO}_{3}$ solution.

Cysteine concentration measurement. The working electrodes tested were placed in the working cell $(2.5 \mathrm{ml})$ with a magnetic micro stirrer inside containing the $1.5 \mathrm{ml}$ of $55 \mathrm{mM}$ phosphate buffer, 
$\mathrm{pH}$ 7.4. After several minutes of incubation with the working buffer to obtain electrochemical equilibrium between the buffer and the electrode, an electro-voltaic cell was ensembled by inserting the liquid junction connecting the working cell with the reference electrode cell. The baseline electric potential (in $\mathrm{mV}$ ) was measured for 3 to $30 \mathrm{~min}$, using an Elmetron CP-401 millivoltmeter with an internal resistance of $20 \mathrm{M} \Omega$. Once the baseline potential had been measured, $20 \mathrm{mM}$ cysteine solution in $55 \mathrm{mM}$ phosphate buffer, $\mathrm{pH}$ 7.4, was added to obtain a final cysteine concentration in the range of 0.01 to $20 \mathrm{mM}$. The measured electrochemical potentials were referred to the reference cysteine concentrations when the electrode signal was stable within of $\pm 2.0 \mathrm{mV}$.

Construction of standard curves of cysteine concentration versus millivolts. The cysteine sensitive electrode was inserted to the measuring cell placed on a magnetic stirrer and $2.5 \mathrm{ml}$ solution of $0.01 \mathrm{mM}, 0.05 \mathrm{mM}, 0.1 \mathrm{mM}, 0.5 \mathrm{mM}, 1 \mathrm{mM}, 5 \mathrm{mM}$, $10 \mathrm{mM}$ or $20 \mathrm{mM}$ cysteine in $55 \mathrm{mM}$ phosphate buffer, $\mathrm{pH}$ 7.4, was added. Then, the working electrode cell was connected with the reference electrode cell by inserting the liquid junction. Measurement of the electrode potential was started after $30 \mathrm{~s}$ of equilibration. The electrode potential was then continuously measured for 3 to $30 \mathrm{~min}$. The electrode electromotoric potential, response rate and potential stability versus the given cysteine concentration were assessed. Diluted cysteine samples were prepared immediately before measurements to diminish the effect of spontaneous cysteine oxidation with atmospheric oxygen.

The obtained results were transformed to a logarithmic relationship according to the Nernst equation:

$\mathrm{E}[\mathrm{mV}]=a+b \log$ [cysteine concentration in $\mathrm{mM}]$

The transformed data were then presented in the graphic form using SigmaPlot v.7.0 program. A triplicate measurement of electrode potential for each cysteine concentration was carried out. Mean and standard deviation ( \pm S.D.) was then calculated and referred to the given cysteine concentration in the standard solution. The obtained values were used for the assessment of the correlation $\left(\mathrm{r}^{2}\right)$ and linear regression equation.

Measuring electrode response time to various cysteine concentrations. To the working cell containing $1.2 \mathrm{ml}$ of $0.01 \mathrm{mM}$ cysteine solution in $55 \mathrm{mM}$ phosphate buffer, $\mathrm{pH} 7.4$, consecutive portions of $0.05 \mathrm{ml}, 0.1 \mathrm{ml}, 0.2 \mathrm{ml}, 0.4 \mathrm{ml}, 0.8 \mathrm{ml}$ or $1 \mathrm{ml}$ of buffered $20 \mathrm{mM}$ cysteine solution were added, and the electrode response time and values of the electrode signal were measured. The electrode response to decreasing cysteine concentrations was assessed by measuring the cysteine concentration in a reaction medium containing cysteine and $[\mathrm{His}-\mathrm{Cu}]^{2+}$ complex in $55 \mathrm{mM}$ phosphate buffer $\mathrm{pH}$ 7.4. This measurement was carried out by adding $0.06 \mathrm{ml}$ of $[\mathrm{His}-\mathrm{Cu}]^{2+}$ complex solution to the working cell with $1.5 \mathrm{ml}$ of $0.6 \mathrm{mM}$ cysteine solution, to obtain a final concentration $0.1 \mathrm{mM} \mathrm{Cu}^{2+}$ ions. The electrode potential was followed for $7 \mathrm{~min}$. The results of the measurements were transformed into cysteine concentration $(\mathrm{mM})$ and expressed as a function of cysteine concentration versus reaction time.

The electrode response time was also assessed when various cysteine concentrations were added to a reaction medium containing $[\mathrm{His}-\mathrm{Cu}]^{2+}$ complex in 55 $\mathrm{mM}$ phosphate buffer. This measurements were carried out by adding of $0.005 \mathrm{ml}$ cysteine solution to the working cell containing $1.5 \mathrm{ml}$ of $[\mathrm{His}-\mathrm{Cu}]^{2+}$ complex at $0.1 \mathrm{mM} \mathrm{Cu}^{2+}$ to obtain a final concentration $0.6 \mathrm{mM}$ cysteine. The electrode potential was followed every $1 \mathrm{~s}$ up to termination of the reaction. The measurement results were transformed on-line into cysteine concentration $(\mathrm{mM})$ and expressed as the function of cysteine concentration versus reaction time.

\section{RESULTS}

The analytical performance of the silver-mercury electrode in comparison to other electrodes tested is present in Table 1. The sil-

Table 1. Properties of electrodes tested

\begin{tabular}{lccccc}
\hline Electrode & Slope $(\mathrm{mV})$ & Intercept $(\mathrm{mV})$ & Response range $(\mathrm{mM})$ & CV (mean, \%) & Correlation coeff. $\left(\mathrm{r}^{2}\right)$ \\
\hline Platinum & -26.5 & 141.5 & $0.01-10$ & 17.6 & 0.91 \\
Copper & -99.7 & -212.1 & $0.10-20$ & 4.6 & 0.94 \\
Graphite & -72.6 & -23.8 & $0.01-5$ & 33.2 & 0.78 \\
Graphite-silver & -115.7 & 124.1 & $0.1-20$ & 43.2 & 0.84 \\
Graphite-silver-cysteine & -150.6 & 41.5 & $0.01-20$ & 41.2 & 0.98 \\
Silver & -86.0 & -175.3 & $0.01-20$ & 14.9 & 0.97 \\
Silver-iodide & -53.7 & -180.7 & $0.01-20$ & 2.51 & 0.96 \\
Silver-mercury & -53.8 & -373.4 & $0.01-20$ & 1.82 & 0.97 \\
\hline
\end{tabular}


Table 2. Silver-mercury electrode response to cysteine concentration (0.01-20.0 $\mathrm{mM})$

\begin{tabular}{lcccc}
\hline Cysteine concentration $(\mathrm{mM})$ & Serie $\mathrm{I}(\mathrm{mV})$ & Serie $2(\mathrm{mV})$ & Serie $3(\mathrm{mV})$ & Mean \pm S.D. (CV\%) \\
\hline 0.01 & -270 & -273 & -283 & $-275 \pm 7(2.5)$ \\
0.05 & -297 & -281 & -265 & $-281 \pm 16(5.7)$ \\
0.10 & -310 & -302 & -296 & $-303 \pm 7(2.3)$ \\
0.50 & -339 & -344 & -344 & $-342 \pm 3(0.8)$ \\
1.00 & -356 & -361 & -362 & $-360 \pm 3(0.9)$ \\
5.00 & -391 & -398 & -399 & $-396 \pm 4(1.1)$ \\
10.0 & -414 & -419 & -420 & $-418 \pm 3(0.8)$ \\
20.0 & -443 & -448 & -450 & $-447 \pm 4(0.8)$
\end{tabular}

ver-mercury electrode has shown perfect linearity, variation of $1.82 \%(\mathrm{CV})$ and the slope value in accordance with that predicted by the Nernst equation. The sliver-mercury electrode was superior to other electrodes in respect to $\mathrm{CV}$ at various cysteine concentrations (Table 2). The lowest cysteine concentration yielding an electrode signal was $0.01 \mathrm{mM}$. The electrode response to various cysteine concentrations is shown in Figs. 1 and 2. The silver-mercury electrode standard curve is shown in Fig. 3. The obtained relationship expressed as linear regression equation parameters for $\log$ [cysteine] versus $\mathrm{mV}$ yielded: regression constant $=-373.43[\mathrm{mV}]$ and slope $(\mathrm{b} 1)=$ -53.82. The correlation coefficient square $\mathrm{r}^{2}=0.97$ (for cysteine concentration in $\mathrm{mM}$ ). The electrode signals versus cysteine concentration satisfactorily conform to the Nernst equation, yielding the molar potential coefficient (slope) of about $54 \mathrm{mV} / \mathrm{p}$ per decade of cysteine concentration (Figs. 1-3). The reproducibility of the standard curve is highest in the cysteine concentration range from 0.1 to $20 \mathrm{mM}$. Removing the results obtained for the two

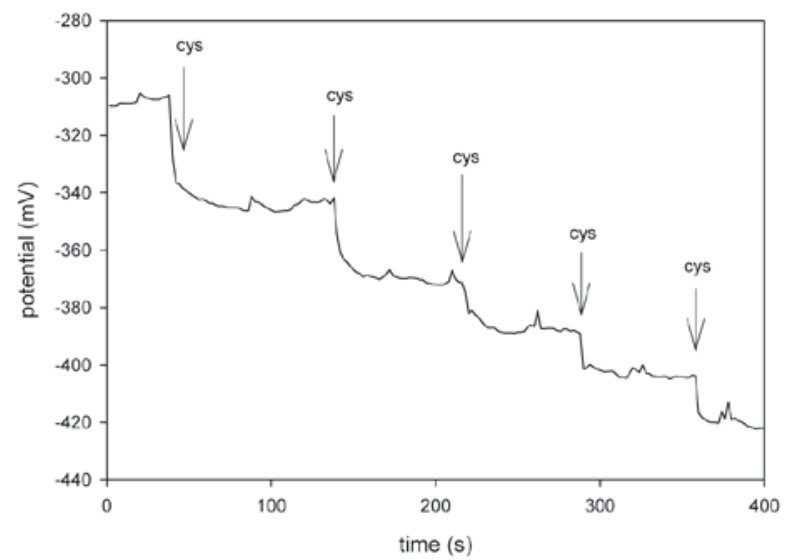

Figure 1. Silver-mercury electrode response to increasing cysteine concentrations.

To $0.01 \mathrm{mM}$ cysteine solution aliquots of $20 \mathrm{mM}$ cysteine were added to obtain final concentrations of $0.01,0.05,1.0$, $5.0,10.0$ or $20.0 \mathrm{mM}$.

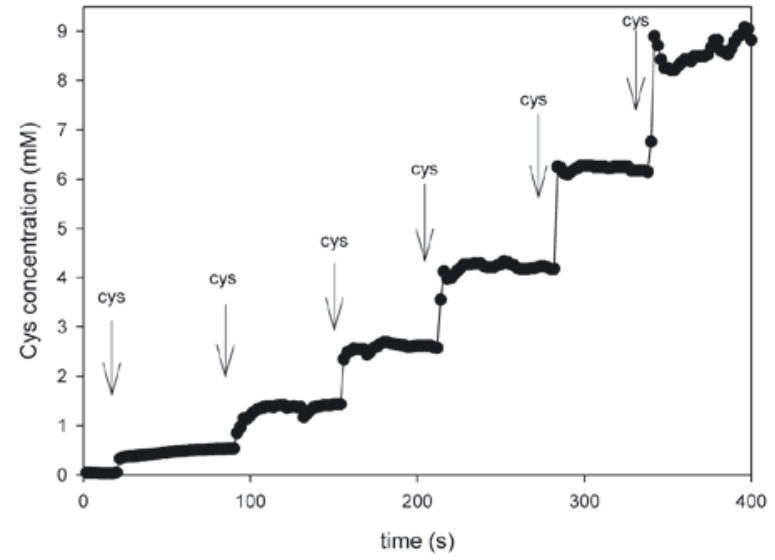

Figure 2. Silver-mercury electrode response expressed in cysteine concentration $(\mathrm{mM})$ occurring at consecutive cysteine additions at $30 \mathrm{~s}$ intervals.

Increasing aliquots of cysteine stock solution $(20 \mathrm{mM})$ were added to the measured sample to give final cysteine concentration of $0.01,0.05,1.0,5.0,10.0 \mathrm{mM}$.

lowest cysteine concentrations $(0.01$ and $0.05 \mathrm{mM})$ from the data did not meaningfully influence the slope value. The electrode response time ranged

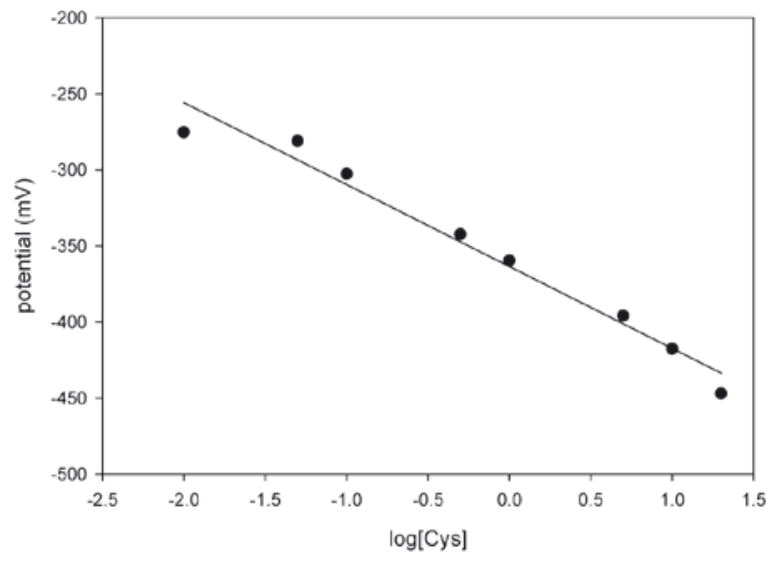

Figure 3. Standard curve for silver-mercury electrode. Electrode response was measured for cysteine concentration range of 0.01 to $20.0 \mathrm{mM} ; \mathrm{mV}=-373.49-53.8 ; \log$ [cysteine $\mathrm{mM}$ ]. 


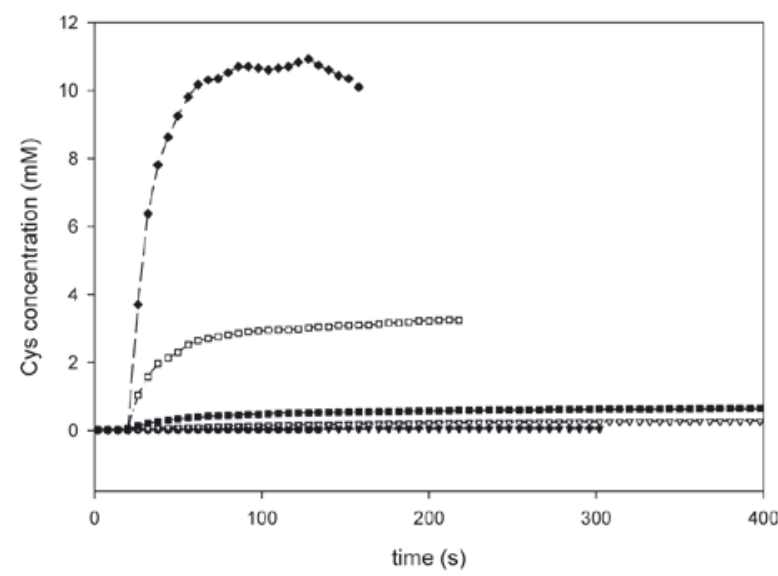

Figure 4. Silver-mercury electrode response time to increasing cysteine concentration.

The response time was measured upon addition of 0.01 $\mathrm{mM}$ (black stars), $0.05 \mathrm{mM}$ (triangles), $1.0 \mathrm{mM}$ (black squares), $5.0 \mathrm{mM}$ (light squares) or $10.0 \mathrm{mM}$ (black diamonds), cysteine solution.

from about $90 \mathrm{~s}$ for cysteine concentrations of 0.01 to $0.1 \mathrm{mM}$ to 20 seconds at higher cysteine concentrations (Fig. 4). The electrode response to consecutive additions of cysteine to the sample is shown on the Figs. 5 and 6. Each addition of cysteine to $[\mathrm{His}-\mathrm{Cu}]^{2+}$ complex solution yields the same electrode response (Fig. 5). The electrode responded to each cysteine addition to the reaction medium (Fig. 6), reacting in the range of 0.05 to $20 \mathrm{mM}$.

The silver-mercury electrode showed certain specificity toward cysteine thiol groups. The electrode responded to the presence of thiol groups of homocysteine and glutathione, however, the mo-

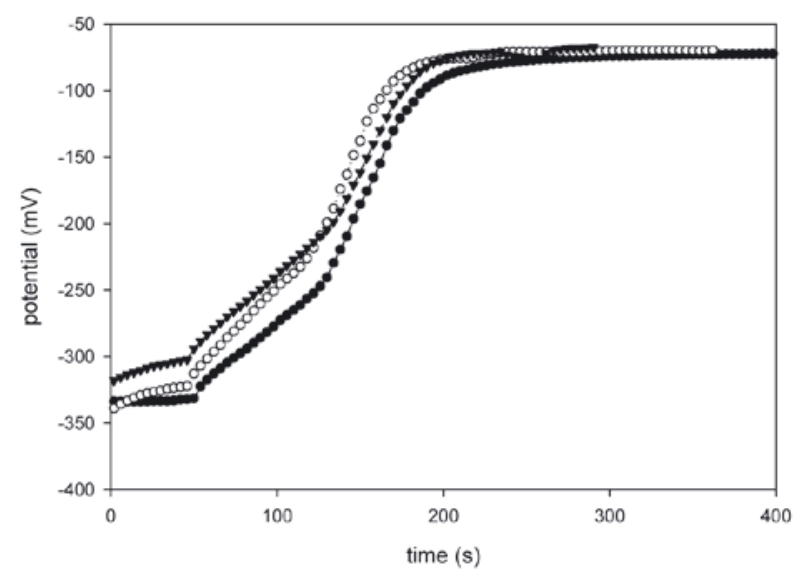

Figure 5. Silver-mercury electrode response to decreasing cysteine concentration.

To $0.6 \mathrm{ml}[\mathrm{His}-\mathrm{Cu}]^{2+}$ complex in $55 \mathrm{mM}$ Na-phosphate buffer $\mathrm{pH} 7.4,0.05 \mathrm{ml}$ of $6 \mathrm{mM}$ cysteine solution in three repetitive experiments was added. Final concentration of $\mathrm{Cu}^{2+}$ ions in solution was $0.1 \mathrm{mM}$.

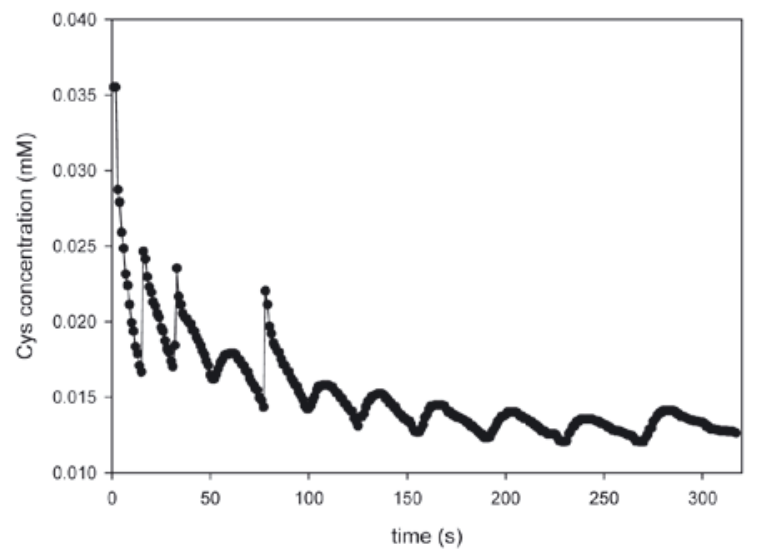

Figure 6. Silver-mercury electrode response to consecutive additions of cysteine.

Electrode response was measured to consecutive additions of cysteine $(0.005 \mathrm{ml}$ of $18 \mathrm{mM})$ at $30 \mathrm{~s}$ intervals to the $[\text { His-Cu }]^{2+}$ complex solution (final concentration of $\mathrm{Cu}^{2+}=$ $0.1 \mathrm{mM})$. At each cysteine addition the electrode monitored increase of the cysteine concentration, then followed by a decrease, due to consumption of cysteine in the reaction medium.

lar potential coefficients were about half of that for cysteine (Table 3).

\section{DISCUSSION}

Monitoring of thiol concentration changes is difficult due to its reactivity with oxygen present in the reaction medium, as well as with various components of the sample. The time consuming multistep sample handling procedures of thiol assays are not suitable for following rapid changes in the concentration of thiols in various reactions. Electrometric procedures reduce both sample handling and the duration of the thiol assay procedure. Jin and Wang (1997) used a mercury-gold amalgam electrode for amperometric determination of cysteine in human plasma, blood and urine. The employed electrochemical system showed a very high analytical sensitivity enabling detection of cysteine in non-deoxygenated solutions, in concentration as low as $5.8 \times 10^{-8} \mathrm{M}$. However, the amperometric assay system with three electrodes is complicated and inconvenient for use in open measurements. Potentiometric determination of cysteine and glutathione was employed earlier in various flow analytical systems, HPLC (Kolar et al., 2000), capillary electrophoresis (Lawrence et al., 2001) or specific flow injection biochemical analyzers (Kolar et al., 2000; 2002) used a potentiometric cysteine and glutathione assay in a flow injection analyzer using silver tubular electrode pretreated with mercuric (II) chloride solution and iodide solution. The sensitivity of such electrode was $10 \mathrm{mM}$ at a slope of $55.2 \pm 1.0 \mathrm{mV} / \mathrm{p}$. In recent papers Kolar 
Table 3. Reactivity of silver-mercury electrode with homocysteine and glutathione

\begin{tabular}{|c|c|c|c|c|c|}
\hline \multicolumn{3}{|c|}{$\begin{array}{l}\text { Homocysteine } \\
\text { Slope }(\mathrm{mV} / \log \mathrm{C})=-28.3 \\
\text { Intercept: }(\mathrm{mV})=-272.4 \\
\mathrm{r}^{2}=0.90\end{array}$} & \multicolumn{3}{|c|}{$\begin{array}{l}\text { Glutathione } \\
\text { Slope }(\mathrm{mV} / \log \mathrm{C})=-18.8 \\
\text { Intercept: }(\mathrm{mV})=-232.8 \\
\mathrm{r}^{2}=0.80\end{array}$} \\
\hline Concentration (mM) & $\begin{array}{l}\text { Mean electrode response } \\
\pm \text { S.D. }(\mathrm{mV})\end{array}$ & CV $(\%)$ & Concentration $(\mathrm{mM})$ & $\begin{array}{l}\text { Mean electrode response } \\
\pm \text { S.D. }(\mathrm{mV})\end{array}$ & $\mathrm{CV}(\%)$ \\
\hline 0.01 & $-229 \pm 2$ & 0.7 & & & \\
\hline 0.05 & $-232 \pm 7$ & 2.9 & - & - & - \\
\hline 0.1 & $-239 \pm 8$ & 3.5 & - & - & - \\
\hline 0.5 & $-252 \pm 12$ & 5.0 & 0.5 & $-216 \pm 6$ & 2.9 \\
\hline 1 & $-265 \pm 14$ & 5.3 & 1 & $-246 \pm 18$ & 7.4 \\
\hline 5 & $-291 \pm 20$ & 7.0 & 5 & $-265 \pm 31$ & 11.7 \\
\hline 10 & $-315 \pm 18$ & 5.7 & 10 & $-297 \pm 4$ & 1.4 \\
\hline- & - & - & 20 & $-353 \pm 21$ & 6.5 \\
\hline
\end{tabular}

et al. (2002) and Kolar \& Dobcnik (2000) employed chemically modified silver electrodes designed for batch analysis or flow analysis of samples containing cysteine and $\mathrm{N}$-acetylcysteine. The electrode was prepared by pretreatment of silver wire or silver tube with mercuric (II) chloride and potassium iodide. The electrodes had a constant linear response within a concentration range of $4 \mu \mathrm{M}$ to $1 \mathrm{mM}$ at a slope of $60.6 \pm 1 \mathrm{mV} / \mathrm{p}$ for $N$-acetylcysteine and sensitivity of $5 \mathrm{mM}$ at a slope of $53.4 \pm 1 \mathrm{mV} / \mathrm{p}$ for cysteine. These electrodes, however, were dedicated to drug analysis in a batch or a special flow analyzer and were unsuitable for our purpose of monitoring cysteine concentration in the small samples used in our studies. However, the results presented by those authors indicated potential favorable analytical properties of the silver-mercury electrode for thiol concentration monitoring.

Our present studies showed that a simple silver-mercury electrode activated with cysteine offered the best analytical performance of the eight electrodes tested. The thiol measurement system employed in our studies, composed of a silver-mercury working electrode, a silver-chloride reference electrode and a liquid junction with $1 \mathrm{M} \mathrm{KNO}_{3}$ in $1 \%$ agarose was the most suitable one for monitoring changing cysteine concentrations (Table 2). The electrode had a perfect reproducibility and was easy to handle, thanks to the silver wire shock resistance. The molar potential coefficient (S-slope) amounting to $53.8 \mathrm{mV} / \mathrm{p}$ is in accord with that predicted by the Nernst equation. The electrode employed in our studies appeared to perform properly in the phosphate buffer solution, $\mathrm{pH} 7.4$, and in the presence of the $[\mathrm{His}-\mathrm{Cu}]^{2+}$ complex. The mechanism of the reaction occurring on the surface of the mercury or silver-mercury electrodes is highly complex and depends on the $\mathrm{pH}$ of the reaction medium. Heyrovsky et al. (1997) indicated that on the surface of a mercury electrode cysteine is transformed to mercuric thiolate, which produces a secondary complex with the electrode surface, additionally employing the cysteine nitrogen atom:

$$
\begin{aligned}
& \mathrm{Hg}^{0} \leftrightarrow \mathrm{Hg}^{+}+\mathrm{e}^{-} \\
& \mathrm{Hg}^{+}+\mathrm{RSH} \rightarrow[\mathrm{Hg}(\mathrm{RS})]_{\mathrm{ads}}+\mathrm{H}^{+} \\
& {[\mathrm{Hg}(\mathrm{RS})]_{\mathrm{ads}}+\mathrm{RSH} \rightarrow\left[\mathrm{Hg}(\mathrm{RS})_{2}\right]+\mathrm{H}^{+}}
\end{aligned}
$$

The mechanism of action of the silver-mercury electrode is probably similar to that of the mercury electrode, but due to the complexity of reactions occurring on the electrode surface, prediction of the electrode properties was not possible.

Thiol compounds represent an important part of the oxidation-reduction balance of organisms. The cysteine-glutathione system is considered to be involved in the reduction of lipid and protein peroxides, and participates in the defense against reactive oxygen species (ROS). Thiol groups of free and protein-bound cysteine residues play a protective role for the active centers of many enzymes and ascertain the stability of various structural proteins. However, cysteine can also participate in reactive oxygen species production, thus enhancing the damaging effects of ROS on the biological structures (Kachur et al., 1999), and the use of the silver-mercury electrode described in our study may facilitate the investigation of cysteine reactions in various biological systems where free radical formation may potentially occur.

\section{Acknowledgement}

Studies supported by Collegium Medicum grant No. BBN/CM - 4100/547/2006/501/P/222/L. 


\section{REFERENCES}

Calvo-Marzal P, Chumbimuni-Torres KY, Hoehr NF, Kubota LT (2006) Determination of glutathione in hemolysed erythrocyte with amperometric sensor based on TTF-TCNQ. Clin Chim Acta 371: 152-158.

Heyrovsky M, Mader P, Vavricka S, Vesela V, Fedurco M (1997) The anodic reactions at mercury electrode due to cysteine. J Electroanal Chem 430: 103-117.

Hidayat A, Hibbert DB, Alexander PW (1997) Amperometric detection of organic thiols at a tungsten wire electrode following their separation by liquid chromatography. J Chromatogr B 693: 139-146.

Jin W, Wang J (1997) Determination of cysteine by capillary zone electrophoresis with end-column amperometric detection at a gold/mercury amalgam microelectrode without deoxygenation. J Chromatogr A 769: 307-314.

Kachur AV, Koch CJ, Biaglow JE (1999) Mechanism of copper-catalyzed autoxidation of cysteine. Free Radic Res 31: 23-34.

Kolar M, Dobcnik D (2003) Chemically prepared silver electrode for determination of $N$-acetyl-L-cysteine by flow-injection potentiometry. Pharmazie 58: 25-28.

Kolar M, Dobcnik D, Radic N (2000) Potentiometric flow injection determination of vitamin $\mathrm{C}$ and glutathione with a chemically prepared silver tubular electrode. Pharmazie 55: 913-917.
Kolar M, Dobcnik D, Radic N (2002) Chemically treated silver electrodes for determination of cysteine. Microchem Acta 138: 23-27.

Lawrence NS, Davis J, Compton RG (2001) Electrochemical detection of thiols in biological media. Talanta 53: 1089-1094.

Ozoemena K, Westbroek P, Nyokong T (2001) Long-term stability of a gold electrode modified with a self assambled monolayer of octabutylthiophtalocyaninatocobalt(II) towards L-cysteine detection. J Electrochem Commun 3: 529-534.

Sugawara K, Hoshi S, Akatsuka K, Shimazu K (1996) Electrochemical behaviour of cysteine at a Nafion ${ }^{\mathrm{R}} /$ cobalt(II) modified electrode. J Electroanal Chem 414: 253-256.

Yang W, Gooding JJ, Hibbert BB (2001) Characterization of gold electrodes modified with self-assambled monolayers of L-cysteine for the adsorptive stripping analysis of copper. J Electroanal Chem 516: 10-16.

Yosypchuk B, Novotny L (2002) Cathodic stripping voltametry of cysteine using silver and copper solid amalgam electrodes. Talanta 56: 971-976.

Zhao C, Zhang J, Song J (2001) Determination of L-cysteine in amino-acid mixture and human urine by flow-injection analysis with a biamperometric detector. Anal Biochem 297: 170-176. 